\title{
59. DATA REPORT: GEOCHEMICAL LOGGING RESULTS FROM THE LAU BASIN AND TONGA RIDGE: SITES 834, 838, 839, AND 840
}

\author{
Elizabeth Lewis Pratson, ${ }^{2}$ Cristina Broglia, ${ }^{2}$ Lana B. Billeaud, ${ }^{2}$ and Robin R. Reynolds ${ }^{2}$
}

\begin{abstract}
Geochemical well logs were obtained through sediment at Sites 838 and 840 and through sediment and basalt at Sites 834 and 839 of Leg 135. Corrections have been applied to the logs to account for variations in borehole size, drilling-fluid composition. and drill-pipe attenuation. Concentrations of Th, $\mathrm{U}$, and Gd, as well as oxide weight percentages, have been calculated from the logs. The log-derived geochemistry correlates well with shipboard $\mathrm{CaCO}_{3}$ measurements in each well. The X-ray fluorescence (XRF) measurements compare well with the geochemical log values at each of the logged sites, except in zones of alteration.
\end{abstract}

\section{INTRODUCTION}

Ocean Drilling Program (ODP) Leg 135 took place in the Lau Basin and on the adjacent Tonga Ridge in the South Pacific Ocean. Eight sites were drilled on Leg 135: six in the Lau Basin backarc (Sites 834-839) to produce an east-west transect of the basin, and two outside the basin (Sites 840-841) to investigate the Tonga Ridge and Tonga forearc (Fig. 1; Parson, Hawkins, Allan, et al., 1992, pp. 5-47).

Four of the drilled sites were logged with the geochemical tool string (Sites $834,838,839$, and 840 ). The geochemical tool string measures the major elements of a formation at intervals of $0.1524 \mathrm{~m}$. The geochemical measurements provide continuous, in-situ measurements that are not affected by incomplete core recovery or core expansion, problems that core-based studies often encounter.

This report describes the basic principles of the geochemical tool string and outlines the post-cruise processing techniques. It then briefly compares the geochemical logs with lithologic core descriptions and available core measurements. It focuses on presenting the data and explaining how the data were derived; lithologic interpretation from the logs is performed only where appropriate.

\section{GEOCHEMICAL TOOL STRING}

The geochemical logging tool string (GLT) consists of four separate logging tools: the natural gamma-ray tool (NGT), the compensated neutron tool (CNT), the aluminum activation clay tool (AACT), and the gamma-ray spectrometry tool (GST; GLT, NGT, CNT, AACT, and GST are trademarks of Schlumberger; Fig. 2). These four tools use three separate modes of gamma-ray spectroscopy for a comprehensive elemental analysis of the formation. The natural gamma-ray tool is located at the top of the tool string so that it can measure the naturally occurring radionuclides, thorium (Th), uranium (U), and potassium $(\mathrm{K})$ before the formation is irradiated by the nuclear sources contained in the lower tools. The CNT, located below the NGT, carries a low-energy californium-252 $\left({ }^{252} \mathrm{Cf}\right)$ neutron source to activate the aluminum $(\mathrm{Al})$ atoms in the formation. The AACT, a modified NGT, is located below the ${ }^{252} \mathrm{Cf}$ source, measuring the activated gamma-rays in the formation. By combining the AACT measurement with the previous NGT measurement, the background radiation is subtracted out and a reading of formation $\mathrm{Al}$ is obtained (Scott and

\footnotetext{
${ }^{1}$ Hawkins. J.. Parson, L.. Allan. J., et al.. 1994. Proc: ODP. Sci. Results, 135: College Station. TX (Ocean Drilling Program).

${ }^{2}$ Borehole Research Group, Lamont-Doherty Geological Observatory of Columbia University. Palisades, NY 10964, U.S.A.
}

Smith, 1973). The gamma-ray spectrometry tool, at the base of the string, carries a pulsed neutron generator to induce prompt-capture gamma-ray reactions in the borehole and formation and an $\mathrm{NaI}(\mathrm{TI})$ scintillation detector to measure the energy spectrum of gamma rays generated by the neutron capture reactions. Because each of the elements in the formation is characterized by a unique spectral signature, it is possible to derive the contribution (or yield) of each of the major elements silicon ( $\mathrm{Si}$ ), iron ( $\mathrm{Fe}$ ), calcium (Ca), titanium (Ti), sulfur $(\mathrm{S})$, gadolinium $(\mathrm{Gd})$, and potassium $(\mathrm{K})$ from the measured spectrum and, in turn, to estimate the relative abundance of each in the formation when combined with the elemental concentrations from the NGT and AACT. The GST also measures the hydrogen $(\mathrm{H})$ and chlorine $(\mathrm{Cl})$ in the borehole and formation, but these elements are not used for determining rock geochemistry.

The only major rock-forming elements not measured by the geochemical tool string are magnesium $(\mathrm{Mg})$ and sodium $(\mathrm{Na})$; the neutron-capture cross sections of these elements are too small relative to their typical abundance's for the tool string to detect. A rough estimate of $\mathrm{Mg}+\mathrm{Na}$ can in some instances be made by using the photoelectric factor (PEF), measured by the lithodensity tool. This measured $\mathrm{PEF}$ is compared with a calculated PEF (a summation of the PEF from all of the measured elements). The separation between the measured and calculated PEF is, in theory, attributable to any element left over in the formation (i.e.. $\mathrm{Mg}$ and $\mathrm{Na}$ ). Further explanation of this technique is found in Hertzog et al. (1989). This calculation was not attempted in this leg; the results of the Mg calculation have been found to be erroneous in ODP holes (Pratson et al., 1993). The inclusion of this unreliable $\mathrm{Mg}+\mathrm{Na}$ curve in the normalization with the other elements would have induced noise into all the other elements. Where available (Holes $834 \mathrm{~B}$ and $839 \mathrm{~B}$ ), $\mathrm{MgO}+\mathrm{Na}_{2} \mathrm{O}$ values from core were included in the normalization step of the processing. This is explained further in Step 5 of the data reduction section below.

\section{DATA REDUCTION}

The well-log data from the Schlumberger tools are transmitted digitally up a wireline and are recorded and processed on the JOIDES Resolution in the Schlumberger Cyber Service Unit (CSU). The results from the CSU are made available as "field logs" for initial shipboard interpretation. Subsequent reprocessing is necessary to correct the data for the effects of fluids added to the well, logging speed, and drill-pipe interference. Processing of the spectrometry data is required to transform the relative elemental yields into oxide weight fractions.

The processing is performed with a set of log-interpretation programs written by Schlumberger that have been slightly modified to account for the lithologies and hole conditions encountered in ODP holes. The steps are summarized below: 


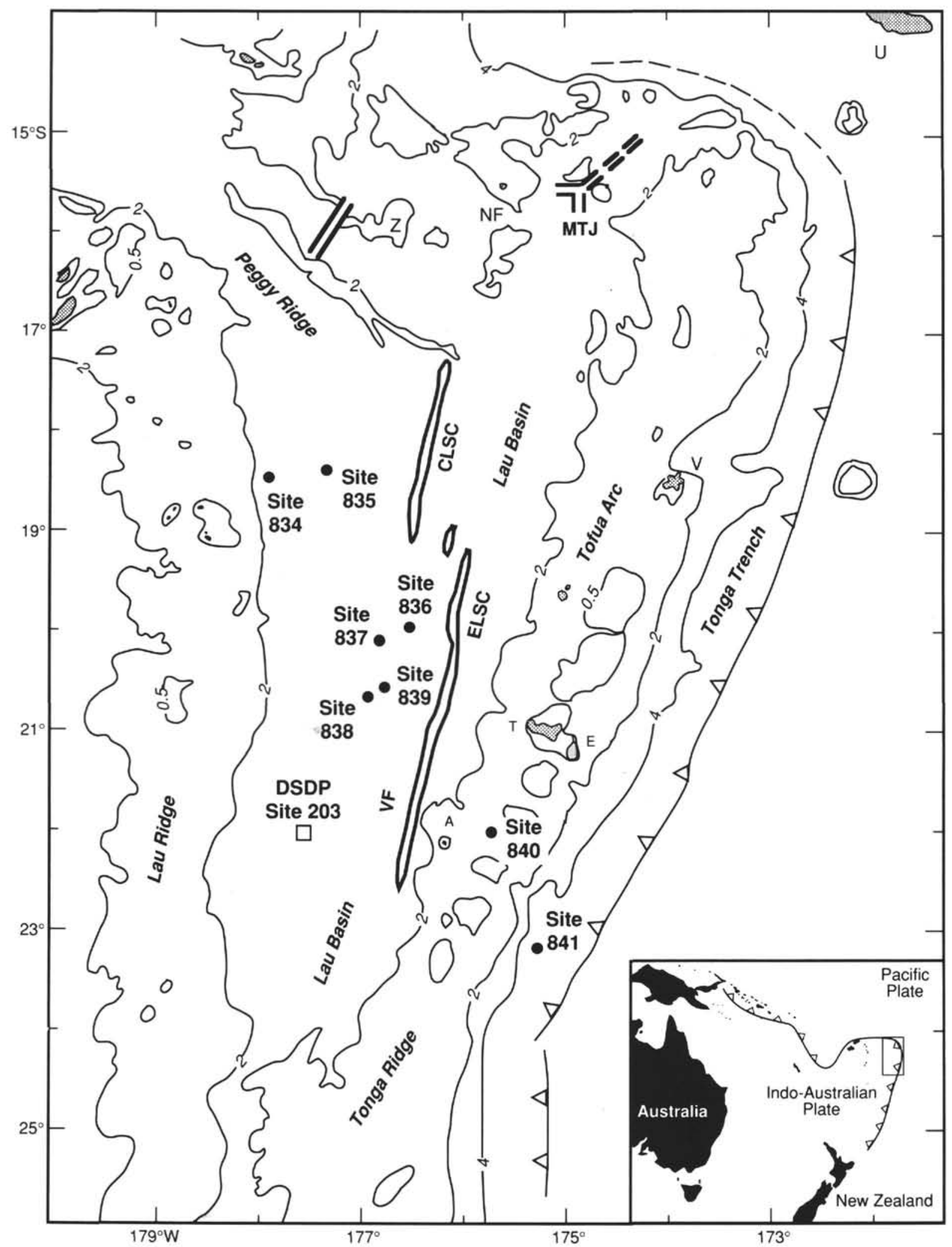

Figure 1. Location of ODP Sites 834-841 and the holes of DSDP Site 203, along with the major geologic features of the Tonga Trench and Lau Basin system. Islands shown are Tongatapu (T), 'Eua (E), 'Ata (A), Vava'u (V). Niuafo'ou (NF), and Upolu (U). The locations of the Central and Eastern Lau spreading centers (CLSC and ELSC, respectively), Valu Fa Ridge (VF), Mangatolu Triple Junction (MTJ), and Zephyr Shoal (Z) are from von Stackelberg (1990), Parson et al. (1990), Hawkins et al. (1989), and Nilsson et al. (1989). The location of DSDP Site 203 is shown as an open box. Contour intervals are in kilometers (after Parson, Hawkins, Allan, et al.. 1992, pp. 5-47). 


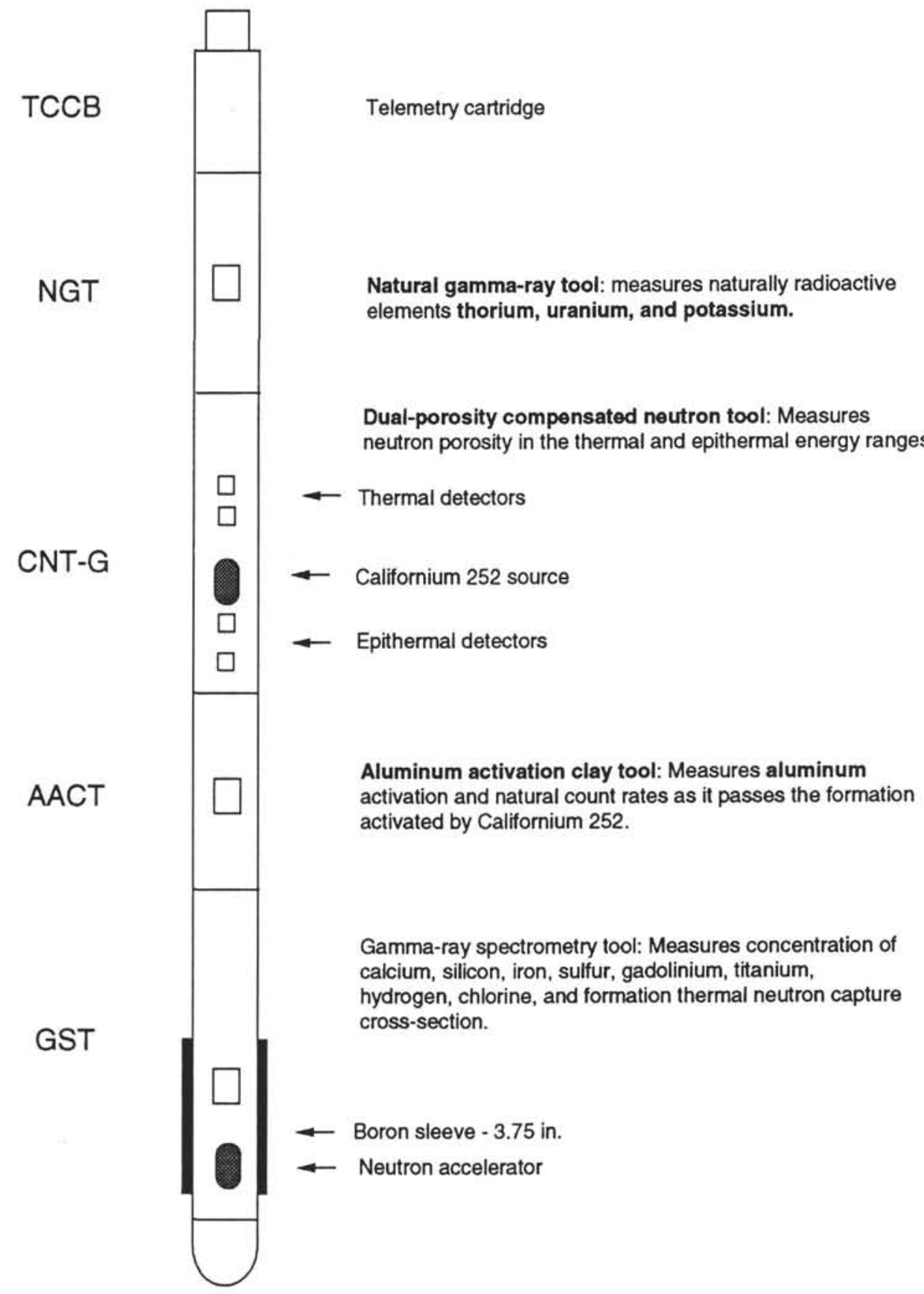

Figure 2. Schematic drawing of the Schlumberger geochemical logging tool string used in the Ocean Drilling Program.

\section{Reconstruction of Relative Elemental Yields from Recorded Spectral Data}

This first processing step compares the measured spectra from the gamma-ray spectrometry tool with a series of "standard" spectra to determine the relative contribution (or yield) of each element. These "standards" approximate the spectrum of each element. Using a weighted, least-squares inversion method, the relative elemental yields are calculated at each depth.

Six elemental standards ( $\mathrm{Si}, \mathrm{Fe}, \mathrm{Ca}, \mathrm{S}, \mathrm{Cl}$, and $\mathrm{H}$ ) are used to produce the shipboard yields, but three additional standards ( Ti, Gd, and $\mathrm{K}$ ) can be included in the post-cruise processing to improve the fit of the spectral standards to the measured spectra (Grau and Schweitzer, 1989). Although Ti, Gd, and K commonly appear in the formation in very low concentrations, they can make a large contribution to the measured spectra because they have large neutron-capture cross sections. For example, the capture cross section of Gd is 49,000 barns, whereas that of $\mathrm{Si}$ is 0.16 barns (Hertzog et al., 1989). Therefore, including Gd is necessary when calculating the best fit of the standard spectra to the measured spectrum.

The spectral analysis was performed using the spectral standards for $\mathrm{Si}, \mathrm{Ca}, \mathrm{Fe}, \mathrm{Ti}, \mathrm{Gd}, \mathrm{H}$, and $\mathrm{Cl}$ only in each of the processed holes. The spectral standards for $\mathrm{K}$ and $\mathrm{S}$ were not used because these two elements existed in concentrations below the resolution of the tool and including them was found to increase significantly the noise level of all the other yields. A straight, seven-point $(3.5 \mathrm{ft}, 1.066 \mathrm{~m})$ smoothing filter was applied to all the yields in each of the holes to reduce the noise in the data during this reconstruction step. An additional 
10-point ( $5 \mathrm{ft}, 1.524 \mathrm{~m}$ ) smoothing filter was applied to Holes $834 \mathrm{~B}$, $838 \mathrm{~B}$, and $839 \mathrm{~B}$ and a five-point $(2.5 \mathrm{ft}, 0.762 \mathrm{~m})$ smoothing filter was applied to Hole $840 \mathrm{~B}$. This additional filter was needed to reduce the noise level further in the normalization factor (explained in Step 5 ), which affects the output elemental yields.

\section{Depth Shifting}

Geochemical processing involves the integration of data from the different tool strings; consequently, it is important that all the data are depth-correlated to one reference logging run. The NGT, run on each of the logging tool strings, provides a spectral gamma-ray curve with which to correlate each of the logging runs. A reference run is chosen on the basis of constant, low cable tension and high cable speed (tools run at faster speeds are less likely to stick and are less susceptible to data degradation caused by ship heave). The depth-shifting procedure involves picking a number of reference points based on similar log character and then invoking a program that stretches and squeezes the matching logging run to fit the reference logging run.

The geochemical logging pass was chosen as the reference run in Holes $834 \mathrm{~B}$ and $839 \mathrm{~B}$. The first run of the seismic stratigraphic logging pass was chosen as the reference run in Hole 838B. The quad combo and geochemical logging passes were found to be on-depth in Hole 840B; these two represent the references in this hole.

\section{Calculation of Total Radioactivity and $T h, U$, and $K$ Concentrations}

The third processing routine calculates the total natural gamma radiation in the formation, as well as concentrations of $\mathrm{Th}, \mathrm{U}$, and $\mathrm{K}$, using the counts in five spectral windows from the natural gamma-ray tool (Lock and Hoyer, 1971). This routine resembles shipboard processing; however, the results are improved during post-cruise processing by including corrections for hole-size changes and temperature variations. A Kalman filter (Ruckebusch, 1983) is used in the CSU processing at sea to minimize the statistical uncertainties in the logs, which can otherwise create erroneous negative values and anti-correlations (especially between $\mathrm{Th}$ and $\mathrm{U}$ ). An alpha filter has been introduced more recently and is now recommended by Schlumberger for shore-based processing. This filter strongly smoothes the raw spectral counts but keeps the total gamma-ray curve unsmoothed before calculating out the Th, U, and K (C. Flaum, pers. comm., 1988). The outputs of this program are $\mathrm{K}$ (wet wt\%), $\mathrm{U}(\mathrm{ppm})$, and Th (ppm), as well as total gamma rays and computed gamma rays (total gamma rays - U contribution).

\section{Calculation of Al Concentration}

The fourth processing routine calculates the concentration of $\mathrm{Al}$ in the formation using four energy windows recorded on the AACT. During this step, corrections are made for natural radioactivity, borehole-fluid neutron-capture cross section, formation neutron-capture cross section, formation slowing-down length, and borehole size. Porosity and density logs are needed as inputs into this routine to convert the wet-weight percentages of $\mathrm{K}$ and $\mathrm{Al}$ curves to dry-weight percentages. A porosity log is recorded on the geochemical tool string; however, it can only be used as a qualitative measurement as it carries $\mathrm{a}^{252} \mathrm{Cf}$ source rather than the americium-beryllium source needed to make a quantitative measurement. Because the density logs in each of the three holes compared well with shipboard core measurements, a porosity curve was derived from the density log using the equation:

$$
\phi_{l}=\left(\rho_{m}-\rho_{b}\right) /\left(\rho_{m}-\rho_{f}\right) \text {. }
$$

where

$$
\begin{aligned}
& \phi_{t}=\text { percentage porosity, } \\
& \rho_{m}=\text { matrix density (a constant value of } 2.69 \mathrm{~g} / \mathrm{cm}^{3} \text { was used), }
\end{aligned}
$$

$\rho_{b}=$ bulk density from the $\log$ in $\mathrm{g} / \mathrm{cm}^{3}$, and

$\rho_{f}=$ density of fluid $=1.05 \mathrm{~g} / \mathrm{cm}^{3}$.

These calculated porosities showed excellent agreement with core measurements, except in Hole 834B. In this hole a combined porosity curve was derived: density-derived porosity was used in the fresh basalts and a calibrated neutron porosity was used in the altered basalts, which agreed well with core porosity measurements.

A correction is also made for $\mathrm{Si}$ interference with $\mathrm{Al}$; the ${ }^{252} \mathrm{Cf}$ source activates the $\mathrm{Si}$, producing the aluminum isotope ${ }^{28} \mathrm{Al}$ (Hertzog et al., 1989). The program uses the $\mathrm{Si}$ yield from the gamma-ray spectrometry tool to determine the Si background correction. The program outputs dry-weight percentages of $\mathrm{Al}$ and $\mathrm{K}$, which are used in the calculation and normalization of the remaining elements.

\section{Normalization of Elemental Yields from the GST to Calculate the Elemental Weight Fractions}

Relative concentrations of the GST-derived elemental yields can be determined by dividing each elemental yield by a relative spectral sensitivity factor $\left(S_{i}\right)$. This factor is principally related to the thermal neutron-capture cross sections and also to its gamma-ray production and detection probability of each element (Hertzog et al., 1989). The relative elemental concentrations are related to the desired absolute concentrations by a depth-dependent normalization factor $(\mathrm{F})$, as defined by the relationship:

$$
\mathrm{Wt}_{i}=F Y_{i} / \mathrm{S}_{i} \text {, }
$$

where

$\mathrm{Wt}_{i}=$ absolute elemental concentration, and

$Y_{i}=$ relative elemental yield.

The normalization factor is calculated on the basis that the sum of all the elemental weight fractions is unity $(100 \%)$. The closure model handles the absence of carbon and oxygen, which are not measured by this tool string, with the approximation that each of the measurable elements combines with a known oxide or carbonate. The dry weight percent of $\mathrm{Al}$ and $\mathrm{K}$ are normalized with the reconstructed elemental yields to the determine the normalization factor at each depth interval from the following equation:

$$
F\left(\sum_{i} X_{i} Y_{j} / S_{i}\right)+X_{\mathrm{K}} \mathrm{Wt}_{\mathrm{K}}+X_{\mathrm{Al}} \mathrm{Wt}_{\mathrm{Al}}=100,
$$

where

$X_{i}=$ oxide factor: atomic wt of the associated oxide or carbonate of element $i \div$ atomic wt of element $i$,

$X_{\mathrm{K}}=$ oxide factor; atomic wt $\mathrm{K}_{2} \mathrm{O} \div$ atomic wt of $\mathrm{K}$,

$\mathrm{Wt}_{\mathrm{K}}=$ dry $\mathrm{wt} \%$ of $\mathrm{K}$ as determined from the NGT,

$X_{\mathrm{Al}}=$ oxide factor; atomic wt of $\mathrm{Al}_{2} \mathrm{O}_{3} \div$ atomic wt of $\mathrm{Al}$, and

$\mathrm{Wt}_{\mathrm{Al}}=$ dry $\mathrm{wt} \%$ of $\mathrm{Al}$ as determined from the AACT.

The value $X_{i}$ accounts for the $\mathrm{C}$ and $\mathrm{O}$ associated with each element. Table 1 lists the oxide factors used in this calculation. All the measured elements associate with $\mathrm{C}$ and $\mathrm{O}$ in a constant ratio in these lithologies, except for $\mathrm{Ca}$, which associates with $\mathrm{C}$ and $\mathrm{O}$ in one of two ways: $\mathrm{CaCO}_{3}$ or $\mathrm{CaO}$ (Table 1). To convert the measured yields to elements, a dominant oxide factor must be assumed at each depth level. A routine that combines both these oxide factors is implemented here, as suggested by Jim Grau at the Schlumberger-Doll research facility (pers. comm., 1992). When the elemental form of Ca is less than $6 \%, \mathrm{CaO}$ is assumed and an oxide factor of 1.39 is used. When the elemental form of $\mathrm{Ca}$ is greater than $12 \%, \mathrm{CaCO}_{3}$ is assumed and an oxide factor of 2.49 is used. When the elemental form of $\mathrm{Ca}$ is between $6 \%$ and $12 \%$, both forms are assumed to be present, and the oxide factor is linearly interpolated between 1.39 and 2.49 .

The parameters $6 \%$ and $12 \%$ were chosen according to observations of how $\mathrm{Ca}$ occurs in nature; $\mathrm{CaO}$ is not likely to occur in quantities greater than $12 \%$. When $\mathrm{Ca}$ is less than $6 \%$, even in the form of 
Table 1. Oxide factors used in normalizing elements to $100 \%$ and converting elements to oxides.

\begin{tabular}{lll}
\hline \multicolumn{1}{c}{ Element } & Oxide/carbonate & \multicolumn{1}{c}{ Conversion factor } \\
\hline $\mathrm{Si}$ & $\mathrm{SiO}_{2}$ & 2.139 \\
$\mathrm{Ca}<6 \%$ & $\mathrm{CaO}$ & 1.399 \\
$6 \%>\mathrm{Ca}<12 \%$ & $\mathrm{CaO}$ and $\mathrm{CaCO}_{3}$ & $1.399-2.490$ (linearly interpolated) \\
$\mathrm{Ca}>12 \%$ & $\mathrm{CaCO}_{3}$ & 2.490 \\
$\mathrm{Fe}$ & $\mathrm{FeO}^{*}$ & 1.358 \\
$\mathrm{~K}$ & $\mathrm{~K}_{2} \mathrm{O}^{2}$ & 1.205 \\
$\mathrm{Ti}$ & $\mathrm{TiO}_{2}$ & 1.668 \\
$\mathrm{Al}$ & $\mathrm{Al}_{2} \mathrm{O}_{3}$ & 1.899 \\
\hline
\end{tabular}

$\mathrm{CaCO}_{3}$, the error will be small when 1.39 is used as the oxide factor instead of 2.49. The linear interpolation is done to provide a smooth transition and avoid invoking any erroneous chemical changes on the final processed logs. This procedure for $\mathrm{Ca}$ gives the most correct model in most cases and minimizes the error when the model is not exactly correct.

Because we are not able to calculate elements $\mathrm{Mg}$ or $\mathrm{Na}$ from the logs, which may represent up to $16 \%$ of the dry-weight percentage of oxide in these holes (Parson, Hawkins, Allan, et al., 1992, pp. 85-180), we include core information where available. In Hole 834B a constant value of $10 \% \mathrm{MgO}+\mathrm{Na}_{2} \mathrm{O}$ was used in the normalization. In Hole $839 \mathrm{~B}, \mathrm{a} \mathrm{MgO}+\mathrm{Na}_{2} \mathrm{O}$ curve was derived from interpolated core points (with erratic spikes removed) and used in the normalization.

\section{Calculation of Oxide Percentages}

The final routine converts the elemental weight percentages into oxide/carbonate percentages by multiplying each by its associated oxide factor, as shown in Table 1.

\section{COMPARISON OF GEOCHEMICAL LOGS TO CORE}

\section{Site 834}

The processed natural gamma-ray curves from Hole 834B, shown in Figure 3, are displayed next to a lithostratigraphic column (Parson, Hawkins, Allan, et al., 1992, pp. 85-180). The processed NGT curves are derived from the geochemical logging tool string. These NGT logs, which were irradiated below 376 mbsf during tool calibration, have anomalously high gamma-ray values between 376 and 405 mbsf. Figure 4 displays the oxide weight fractions estimated from the logs at Hole 834B, along with calculated statistical uncertainties of each element (Grau et al., 1990; Schweitzer et al., 1988). This error is strongly related to the normalization factor, which is calculated at each depth (Eq. 3). The normalization factor is displayed to the right of the logs. A lower normalization factor represents better counting statistics and higher quality data. A log of the Ca oxide factor is displayed to the right of the factor curve to visually display which $\mathrm{Ca}$ oxide factor was used during calculation. Available core measurements of XRF major elemental analyses are displayed as solid diamonds for comparison with the log data.

Drilling at Site 834 encountered sediments overlain by intercalated sediments and basalts, which were in turn overlain by basalt. Four units, based primarily on clay and vitric ash content of the core, are distinguished within the sedimentary sequence (Parson, Hawkins, Allan, et al., 1992, pp. 85-180). Because the bottom of the pipe is located at the boundary between Units I and II, changes in $\log$ character at this interval are likely a result of the pipe. Unit III is distinguished from Unit II in the core, based on an increase in volcanic silt and vitric ash content. This can be seen on the logs by an increase in total gamma-ray and $\mathrm{K}$ values on the NGT logs. Unit IV is a thin bed of claystone, vitric tuff, and calcarenite intercalated between lava flows. This unit is readily distinguished on the geochemical logs by a large increase in $\mathrm{K}_{2} \mathrm{O}$, and a slight increase in $\mathrm{FeO}^{*}$ from 136 to 139 mbsf.
The igneous rocks recovered from Hole 834B are basalts or low-K tholeiite. Thirteen lithologic units are defined in the igneous sections from Holes 834A and 834B (Parson, Hawkins, Allan, et al., 1992, pp. 85-180), some of which can be distinguished by a change in character on the geochemical logs. The contact between sediment/basalt is marked by a sharp increase in $\mathrm{K}$. The same trend is seen at the contact between lithologic Unit IV and igneous Unit 4. Unit 6 is marked by an increase in $\mathrm{K}_{2} \mathrm{O}, \mathrm{SiO}_{2}, \mathrm{FeO}^{*}, \mathrm{TiO}_{2}$, and $\mathrm{Gd}$ along with a high degree of variability in the curves of $\mathrm{FeO}^{\circ}, \mathrm{Al}_{2} \mathrm{O}_{3}, \mathrm{~K}_{2} \mathrm{O}, \mathrm{TiO}_{2}$, and $\mathrm{Gd}$. The variability of the logs decreases in Unit 7 in the $\mathrm{FeO}^{\circ}, \mathrm{K}_{2} \mathrm{O}, \mathrm{TiO}_{2}$, and $\mathrm{Gd}$ curves. An increase in $\mathrm{K}_{2} \mathrm{O}$ occurs within Unit 8 (2912 mbsf). It increases again at the top of Unit 10 (312 mbsf). At the top of Unit $12, \mathrm{~K}_{2} \mathrm{O}$ decreases in magnitude whereas $\mathrm{TiO}_{2}$ increases markedly (365 mbsf). Log-core agreement is excellent in the upper part of the igneous section (Units 1-5), but it deteriorates in the lower units (Units 6-8). We attribute the discrepancy to a combination of poorer quality hole conditions deeper in the section (creating an unstable normalization factor) and to lower core recovery (which make exact depth placements of core values questionable and inconsistent with reference to log depths).

It was noted in the Initial Reports volume that the raw geochemical logs indicated that Unit 7 had a high silica content, contradicting the XRF chemical analysis (Parson, Hawkins, Allan, et al., 1992, pp. $85-180$ ). The reason for the elevated $\mathrm{Si}$ yield was a decrease in hole size in this unit. When hole size decreases, $\mathrm{Cl}$ and $\mathrm{H}$ decrease, and all of the other rock-forming elemental yields (of which $\mathrm{Si}$ is one) increase. Post-cruise processing removes the effects of borehole size; the elevated $\mathrm{Si}$ is now corrected. It is not recommended that the raw yields be used to infer direct chemical changes without taking into account hole size or porosity variations that significantly affect the character of the yields. The ratio of the yields is instead recommended.

\section{Site 838}

Figure 5 displays the processed NGT logs from the geochemical logging pass in Hole $838 \mathrm{~B}$. Corrections have not been made in these $\log$ to account for pipe attenuation, which affects the logs from 0 to 43 mbsf. The processed NGT curves are derived from the geochemical logging tool string. Figure 6 displays the final oxides, the carbonate core measurements (solid circles), and three XRF samples (solid diamond). Corrections have been attempted to account for the effects of the pipe in the upper $43 \mathrm{~m}$ of the hole; however, because of the low signal-to-noise ratio of these data, caution should still be taken when interpreting any character changes in this upper $43 \mathrm{~m}$ of data.

The sediment at Site 838 is divided into three lithologic units based on changes in sedimentary texture, structure, and composition (Parson, Hawkins, Allan, et al., 1992, 337-395). Unit I has a higher overall $\mathrm{CaO}$ and $\mathrm{CaCO}_{3}$ content than Unit II. Within Units $\mathrm{II}$ and III, $\mathrm{K}_{2} \mathrm{O}$ and $\mathrm{Al}_{2} \mathrm{O}_{3}$ increase from 54 to $125 \mathrm{mbsf}$, indicating an increase in clays or volcaniclastics. Log variability increases between 124 to 148 mbsf, at which point the hole was washed out. Carbonate core measurements agree with open-hole log measurements; however, correlation deteriorates in the through-pipe data. The XRF samples agree well with geochemical logs.

\section{Site 839}

Figure 7 displays the reprocessed NGT curves recorded with the geochemical tool string at Hole 839B. No corrections were performed for pipe attenuation in this hole. Figure 8 displays the final oxides with the carbonate core measurements (solid circles) and three XRF samples (solid diamonds). Through-pipe data are not shown because the pipe masked out any signature from the formation.

Both sediments and basalts were encountered at this site. The sediments were divided into three lithologic units, based primarily on the occurrence of volcaniclastics (Parson, Hawkins, Allan, et al., 1992. 

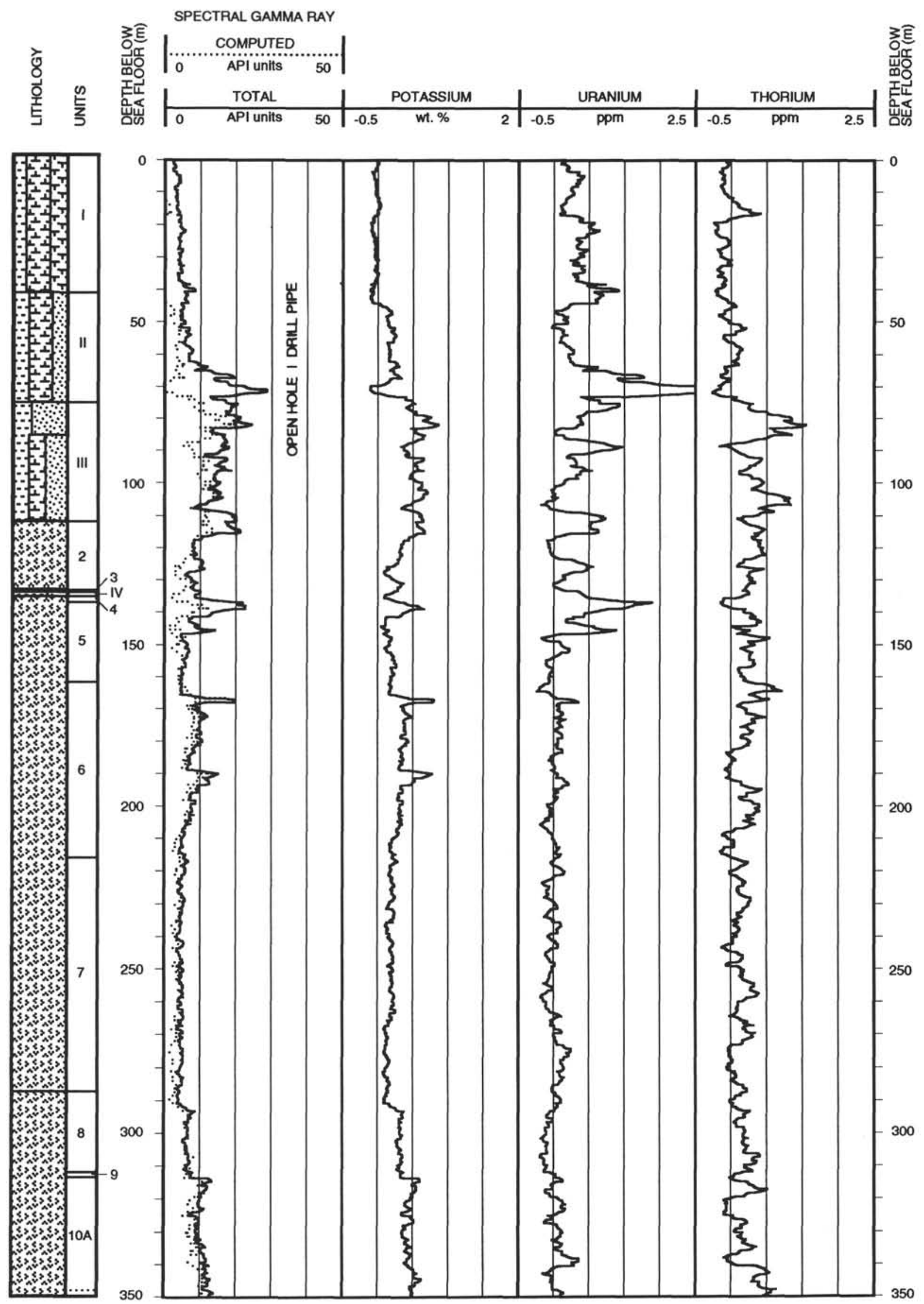

Figure 3. Processed natural gamma-ray data, Hole 834B. 
LEG 135: LEGEND OF LTHOLOGIC SYMBOLS
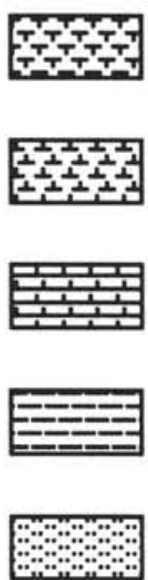

Nannofossil chalk

Silty clay/clayey sitt

Foraminiferal ooze

Nannofossil ooze

Silt, silt/siltstone, volcanic silt

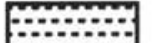

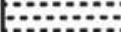

Clay

Sand, sand/sandstone

Gravel

Conglomerate

Basic Igneous
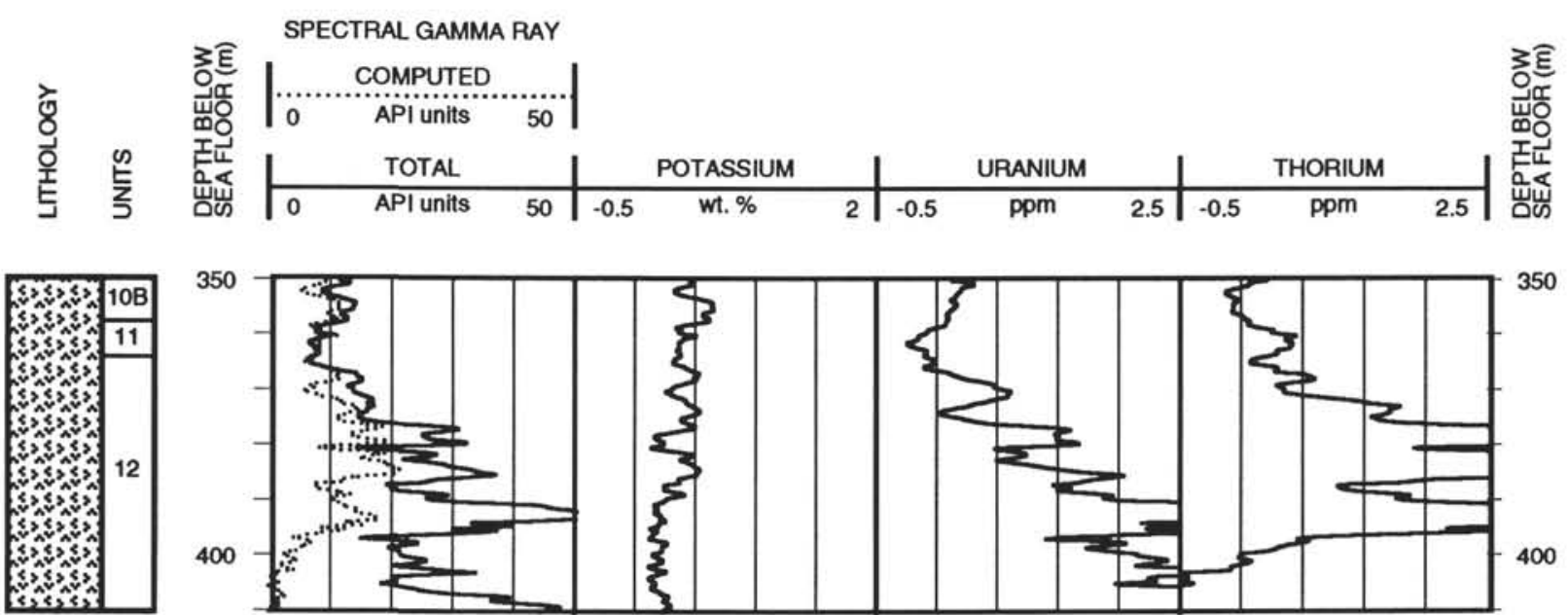

350

400

Figure 3 (continued).

pp. 397-487). Unit II is subdivided into six subunits, based primarily on upward-fining cycles. This cyclicity is tracked on the $\mathrm{K}_{2} \mathrm{O} \log$ in the open-hole sections within Subunits IID-IIF. Recovery was very poor through Unit III; therefore, the lithologic boundaries are not very well constrained. As mentioned in the logging section of the Initial Reports volume (Parson, Hawkins, Allan, et al., 1992, pp. 397-487), the logs support dividing Unit III into two subunits at 162 mbsf, where a change in log character occurs. Below 162 mbsf, $\mathrm{FeO}^{3}$ increases, and $\mathrm{Al}_{2} \mathrm{O}_{3}$ and $\mathrm{K}_{2} \mathrm{O}$ decrease. An anomalously high $\mathrm{FeO}^{\circ}$ content occurs at the base of Unit III, just above the sediment/basalt contact. A thin sedimentary unit occurs within the igneous beds between 257 and 266 mbsf. This is indicated on the logs by an increase in $\mathrm{SiO}_{2}$, $\mathrm{FeO}^{*}$, and $\mathrm{TiO}_{2}$, and by a decrease in $\mathrm{CaO}$ and $\mathrm{CaCO}_{3}$.

Nine igneous lithologic units were defined at Site 839 on the basis of hand specimen and thin section descriptions. Unit 2 resembles Unit 1 in chemical composition, except $\mathrm{K}_{2} \mathrm{O}$ increases within Unit 1 . The geochemical logs indicate that Units 3 and 4 also have similar chemical compositions, yet the logs display slightly more variability, and $\mathrm{CaO}$ and $\mathrm{CaCO}_{3}$ are lower than in Units 1 and 2. Units 5 and 6 are too thin to be discernible on the logs. The $\mathrm{CaO}$ and $\mathrm{CaCO}_{3} \log$ value increases in Unit 7 and $\mathrm{SiO}_{2}$ decreases. Unit 9 has a high $\mathrm{K}_{2} \mathrm{O}$ and $\mathrm{Al}_{2} \mathrm{O}_{3}$ content. Logs agree well with core measurements, with the exception of $\mathrm{Al}_{2} \mathrm{O}_{3}$ within igneous Unit 1. It is possible that this dis- agreement is a result of alteration, which was restricted to basalts in Unit 1 (Parson, Hawkins, Allan, et al., 1992, pp. 397-487). If sampling was selective (i.e., if only fresh material was taken), then a discrepancy such as the one seen here could happen.

\section{Site 840}

The reprocessed NGT logs from Hole 840B are displayed in Figure 9. The data come from the geochemical tool string; corrections have not been made for pipe attenuation. Figure 10 displays the final oxides along with the carbonate core analyses (solid circles) and three XRF samples (solid diamonds). Through-pipe data are not displayed here because of their poor quality and, therefore, unreliability.

The sediments at Site 840 were divided into three lithologic units based on texture, composition, sedimentary structures, and degree of lithification (Parson. Hawkins, Allan, et al., 1992, pp. 489-570). The geochemical logs indicate changes in chemical composition. The $\mathrm{CaO}$ and $\mathrm{CaCO}_{3}$ value is high in the lower part of Unit $\mathrm{I}$, a nannofossil ooze interbedded with vitric silt, vitric sand, and pumiceous gravel. The overall $\mathrm{SiO}_{2}$ content increases in Unit II, indicating an increase in sands and clays within this unit. Unit III is composed of volcaniclastic turbidites, reflected by the cyclicity in the total gamma-ray log. The three core points agree well with the $\mathrm{FeO}, \mathrm{TiO}_{2}, \mathrm{CaO}$, and $\mathrm{CaCO}_{3}$ 

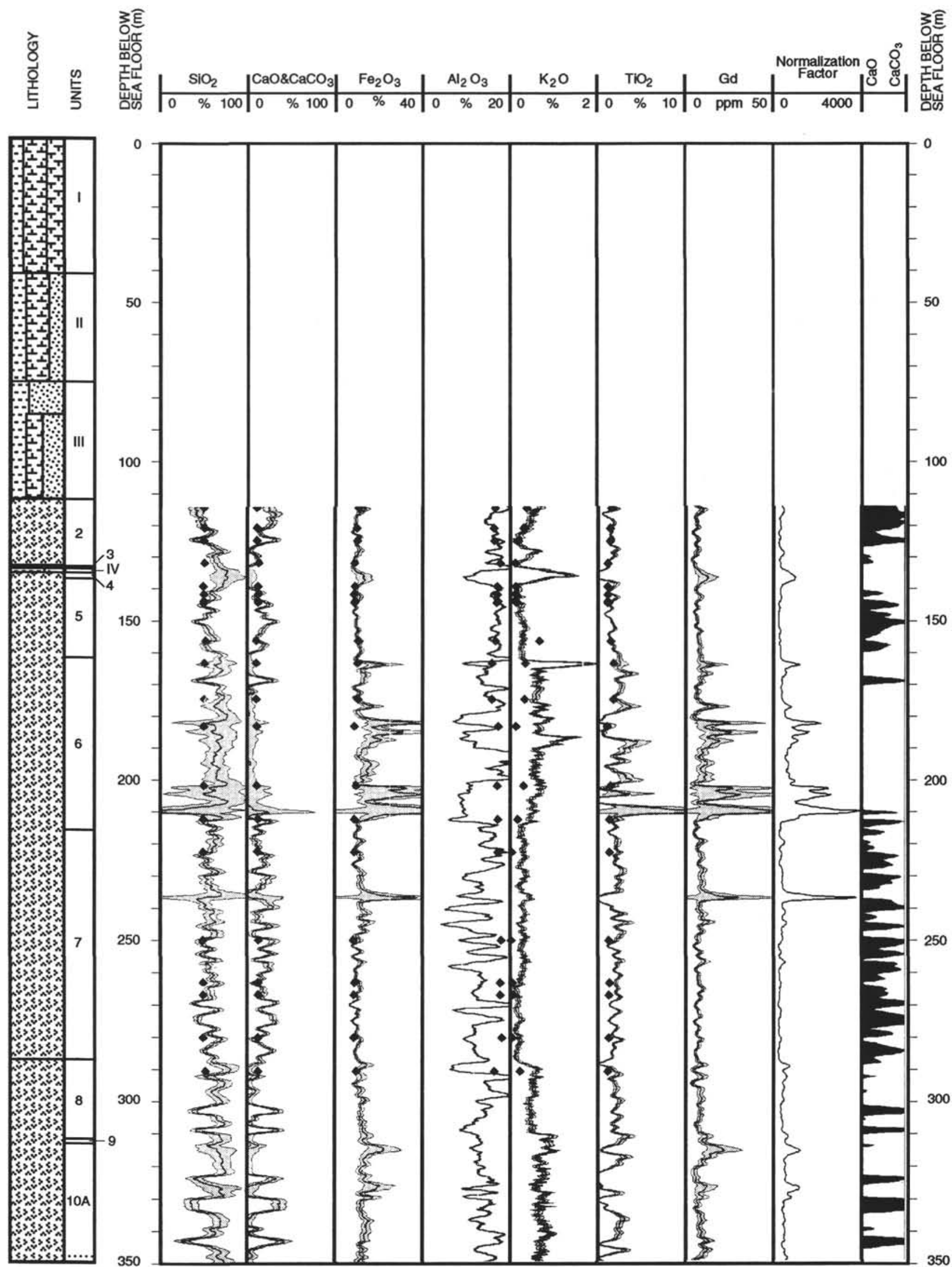

Figure 4. Estimates of calcium carbonate and major oxide-weight fractions from geochemical logs, Hole 834B. Solid diamonds represent XRF measurements, error curves are lighter lines on either side of curve. Legend as in Figure 3 (see also Parson, Hawkins, Allan, et al., 1992, pp. 85-180). 


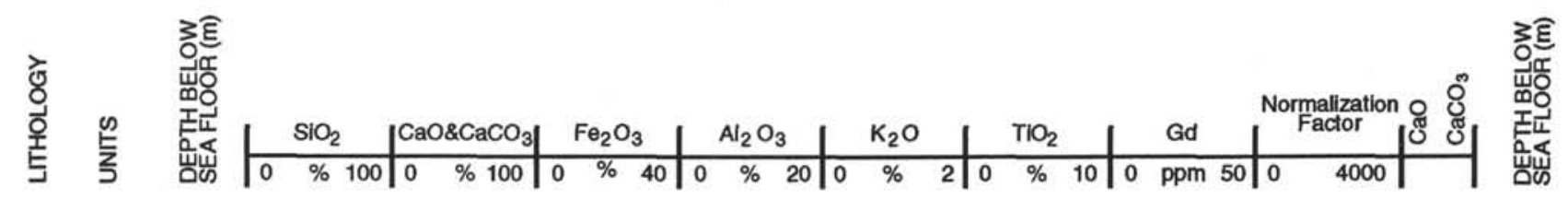
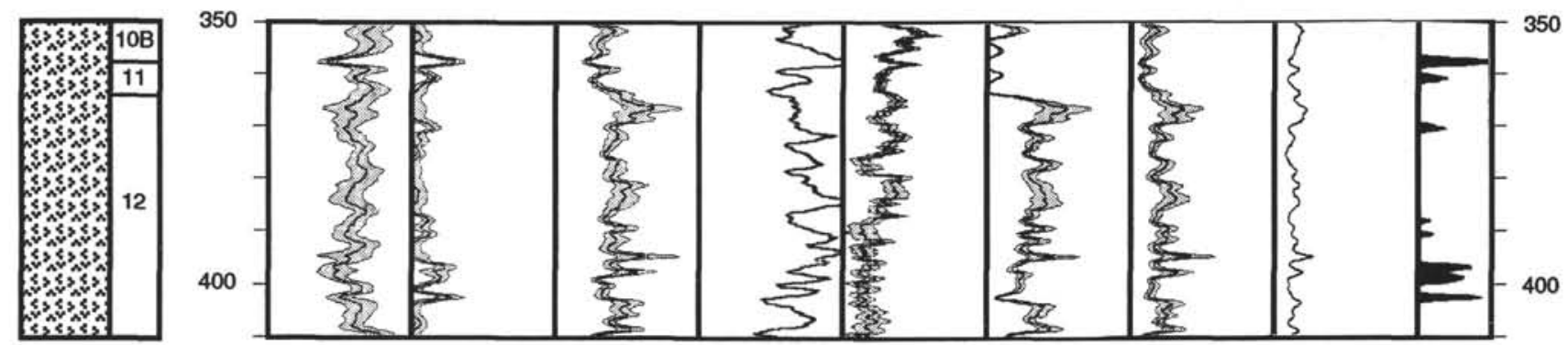

Figure 4 (continued).
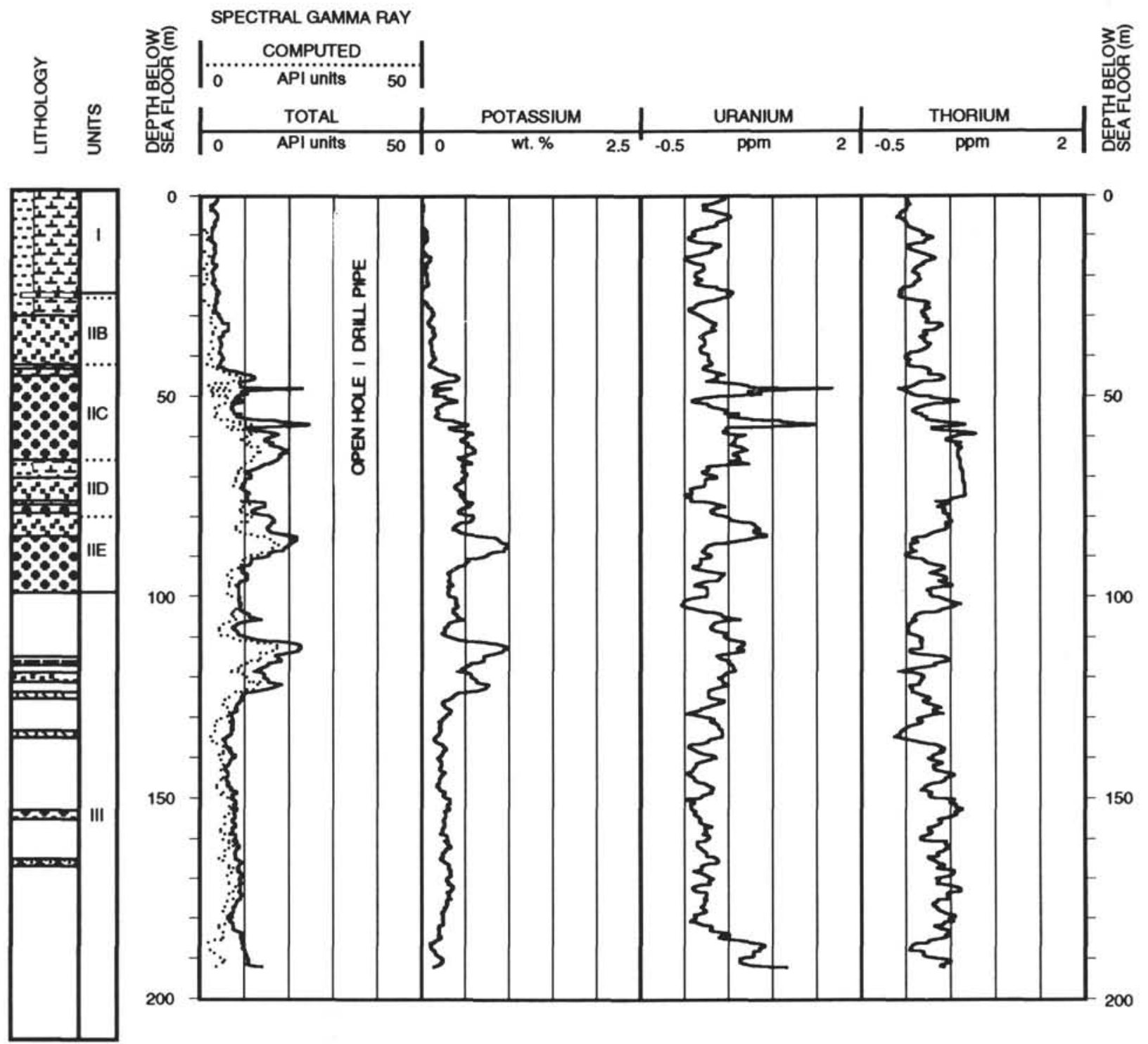

Figure 5. Processed natural gamma-ray data, Hole 838B. Legend as in Figure 3. 
logs, yet the $\mathrm{Al}_{2} \mathrm{O}_{3}$ log values are higher and the $\mathrm{SiO}_{2}$ logs are lower than core values. The cores are not representative, however, of overall core measurements, as they were made on selective pumice clasts.

\section{ACKNOWLEDGMENTS}

We thank Jennifer Tivy for her critical review of the manuscript and her innovative work in creating the final figures.

\section{REFERENCES}

Grau, J.A., and Schweitzer, J.S., 1989. Elemental concentrations from thermal neutron capture gamma-ray spectra in geological formations. Nucl. Geophys., 3:1-9.

Grau, J.A., Schweitzer, J.S., and Hertzog, R.C., 1990. Statistical uncertainties of elemental concentrations extracted from neutron induced gamma-ray measurements. IEEE Trans. Nucl. Sci., 37:2175-2178.

Hawkins, J.W., Melchior, J., Florendo, F., and Nilsson, K., 1989. Evolution of backarc basin magmas and their mantle sources - examples from the Lau Basin and Mariana Trough. Eos, 70:1389.

Hertzog, R., Colson, L., Seeman, B., O'Brien, M., Scott, H., McKeon, D., Wraight, J., Grau, J., Ellis, D., Schweitzer, J., and Herron, M., 1989. Geochemical logging with spectrometry tools. SPE Form. Eval,, 4:153-162.

Lock, G.A., and Hoyer, W.A., 1971. Natural gamma-ray spectral logging. Log Analyst, 12:3-9.

Nilsson, K., Florendo, F.F., and Hawkins, J.W., et al., 1989. Petrology of a nascent triple junction, northeastern Lau Basin. Eos, 70:1389.

Parson, L., Hawkins, J., Allan, J., et al., 1992. Proc. ODP, Init. Repts., 135: College Station, TX (Ocean Drilling Program).
Parson, L.M., Pearce. J.A., Murton, B.J., Hodkinson, R.A., Bloomer, S., Ernewein. M., Huggett, Q.J., Miller, S., Johnson, L., Rodda, P., and Helu, S., 1990. Role of ridge jumps and ridge propagation in the tectonic evolution of the Lau back-arc basin, southwest Pacific. Geology, 18:470-473.

Pratson, E.L., Broglia, C., and Jarrard, R., 1993. Data report: geochemical well logs through Cenozoic and Quaternary sediments from Sites $815,817,820$, 822, and 823. In McKenzie, J.A., Davies, P.J., Palmer Julson, A., et al., Proc. ODP, Sci. Results, 133: College Station, TX (Ocean Drilling Program), 795-817.

Ruckebusch, G., 1983. A Kalman filtering approach to natural gamma ray spectroscopy in well logging. IEEE Trans. Autom. Control, AC-28:372-380.

Schweitzer, J.S., Grau, J.A., and Hertzog, R.C., 1988. Precision and accuracy of short-lived activation measurements for in situ geological analyses. $J$. Trace Microprobe Techn., 6:437-451.

Scott, H.D., and Smith. M.P., 1973. The aluminum activation $\log$. Log Analyst, 14:3-12.

von Stackelberg, U., 1990. R.V. Sonne cruise S048: summary of results testing a model of mineralization. Mar. Min., 9:135-144.

"Abbreviations for names of organizations and publication titles in ODP reference lists follow the style given in Chemical Abstracts Service Source Index (published by American Chemical Society).

Date of initial receipt: 21 July 1992

Date of acceptance: 7 June 1993

Ms 135SR-151 

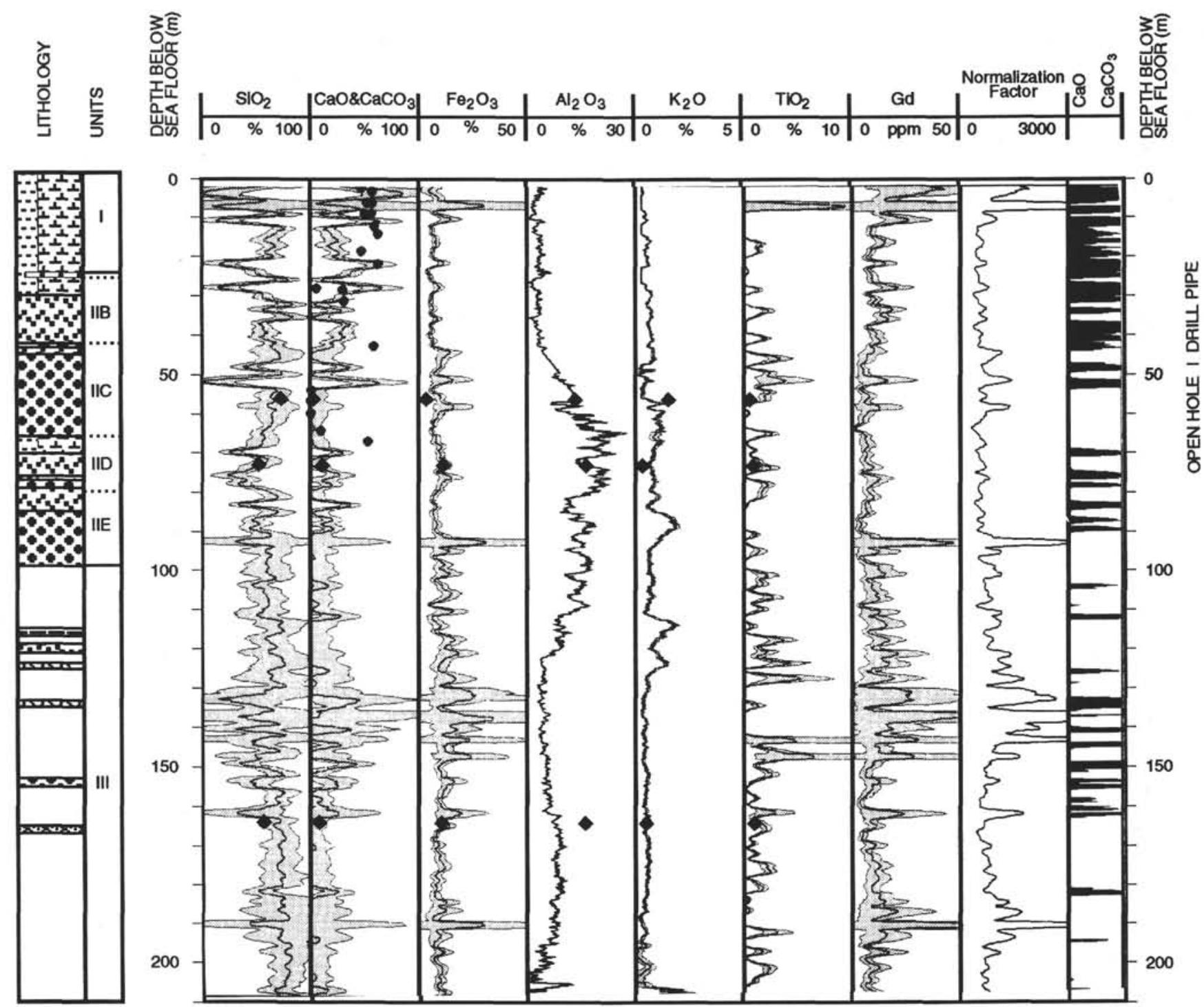

Figure 6. Calcium carbonate and major oxide-weight fractions from geochemical logs run in Hole 838B compared with core measurements. Legend as in Figure 3. 


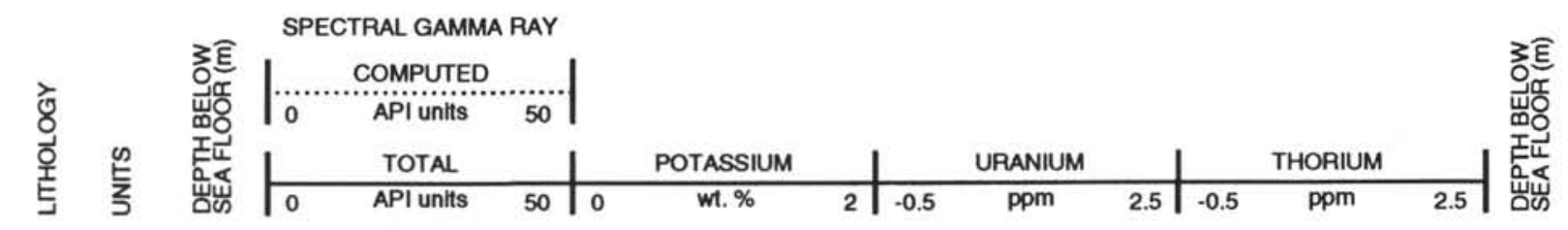

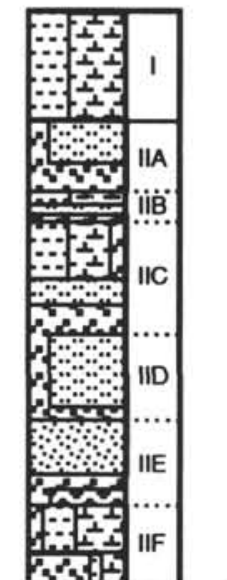
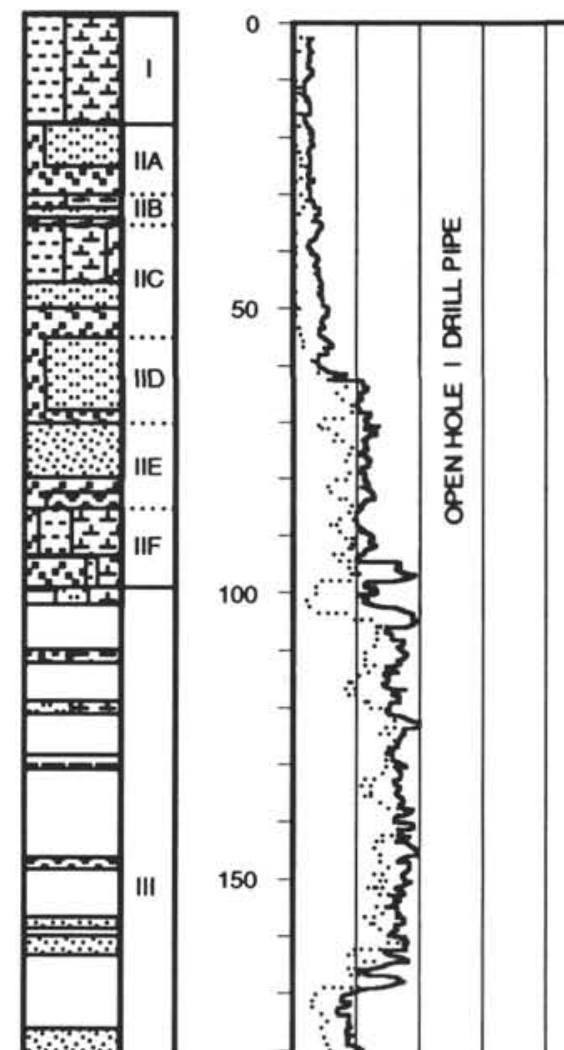

काला

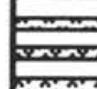

(i)

aris

(a)

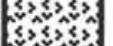

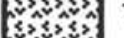

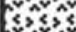

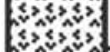

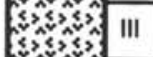

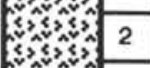

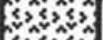

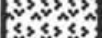

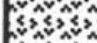

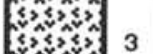

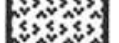

sing

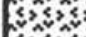

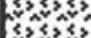

(s) $3 \leqslant \leqslant \leqslant$

(a)

(sis<s?

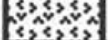

150
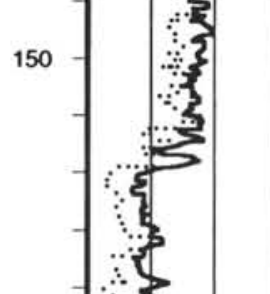

200

$\therefore$ दो

250

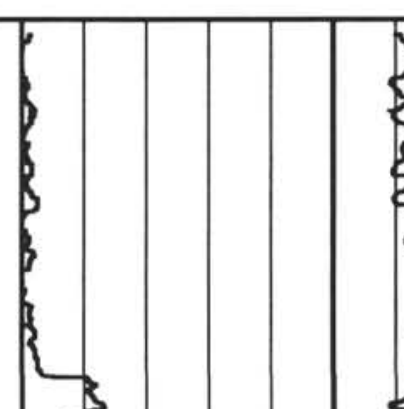

3

$100-1.3$

$\therefore$. ट

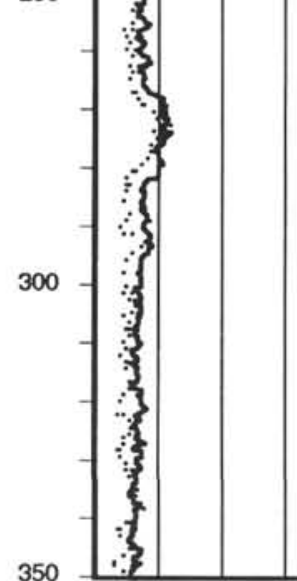

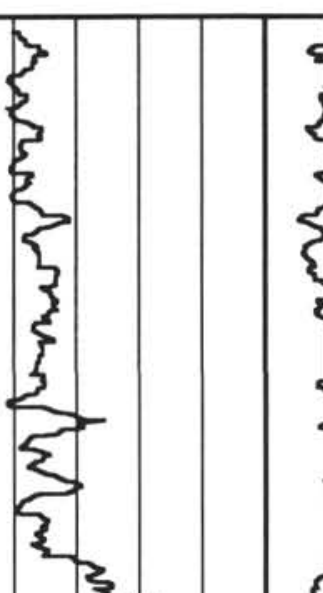

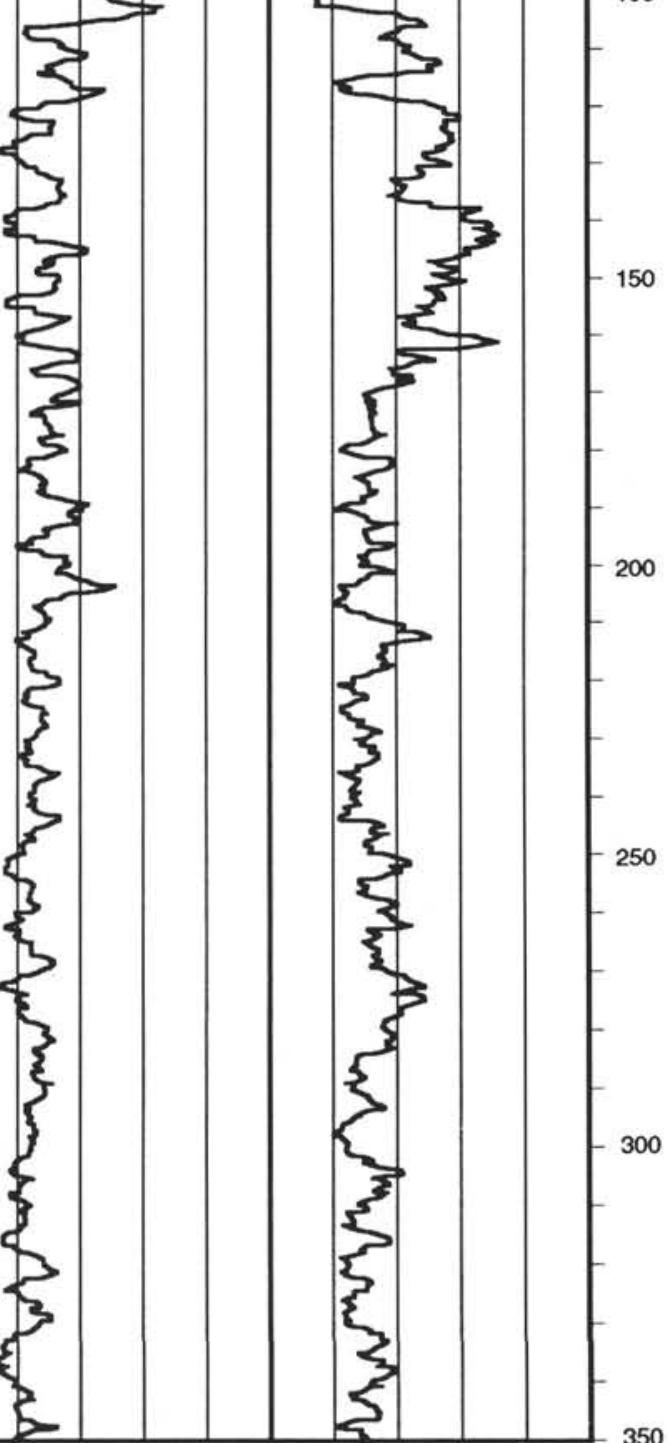

Figure 7. Processed natural gamma-ray data, Hole 839B. Legend as in Figure 3. 

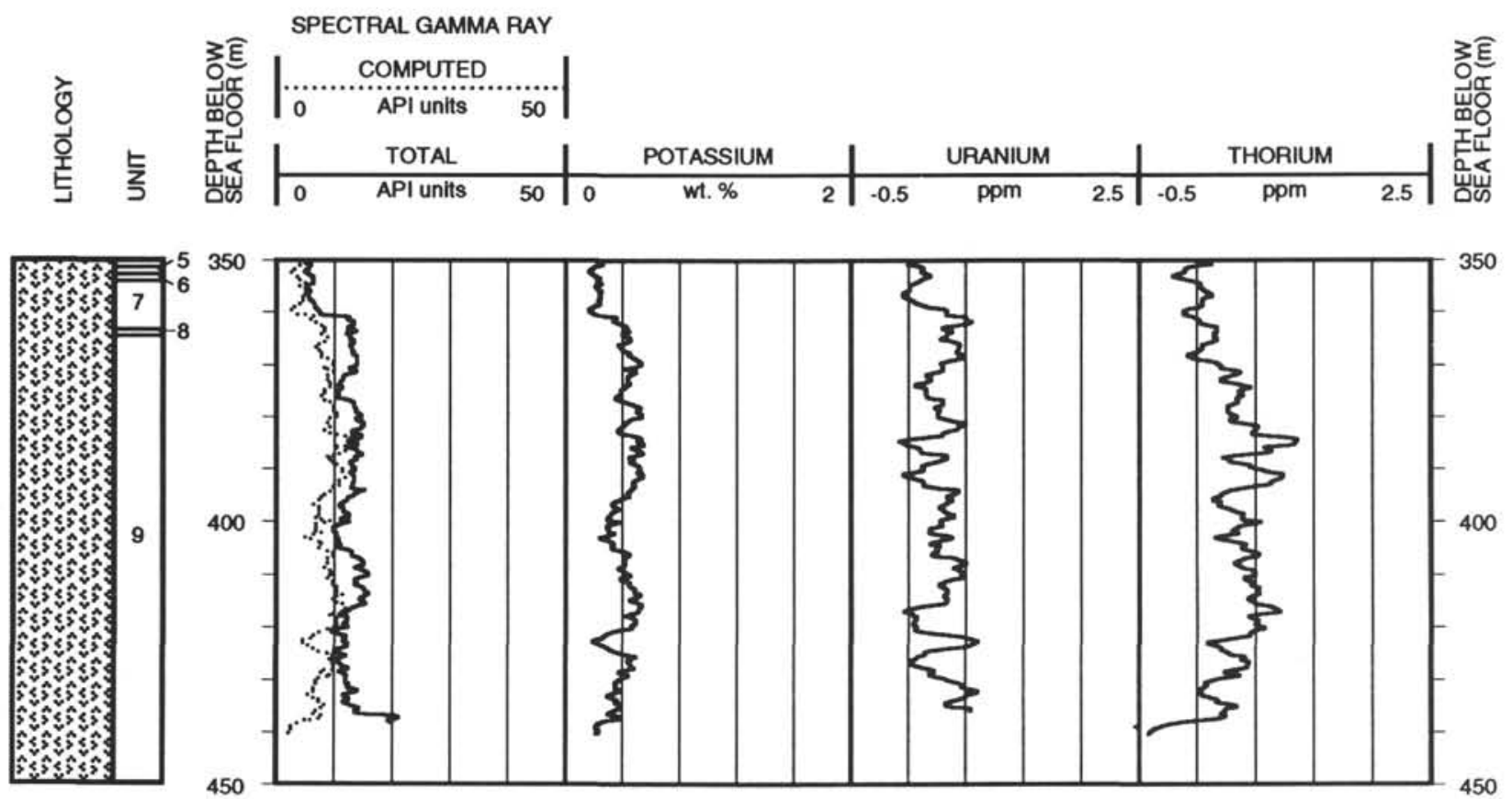

Figure 7 (continued). 

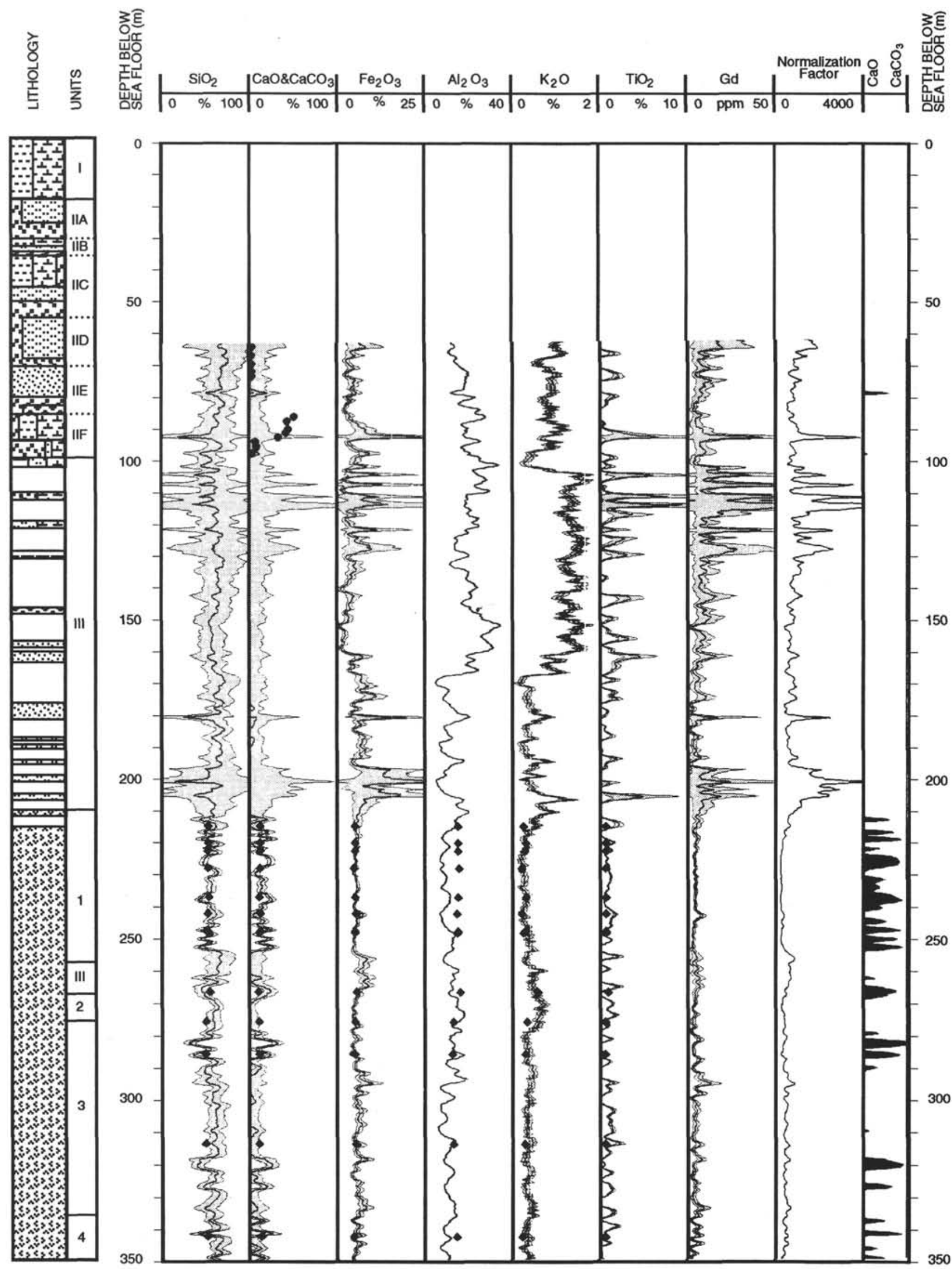

Figure 8. Calcium carbonate and major oxide-weight fractions from geochemical logs run in Hole 839B compared with core measurements. Legend as in Figure 3. 

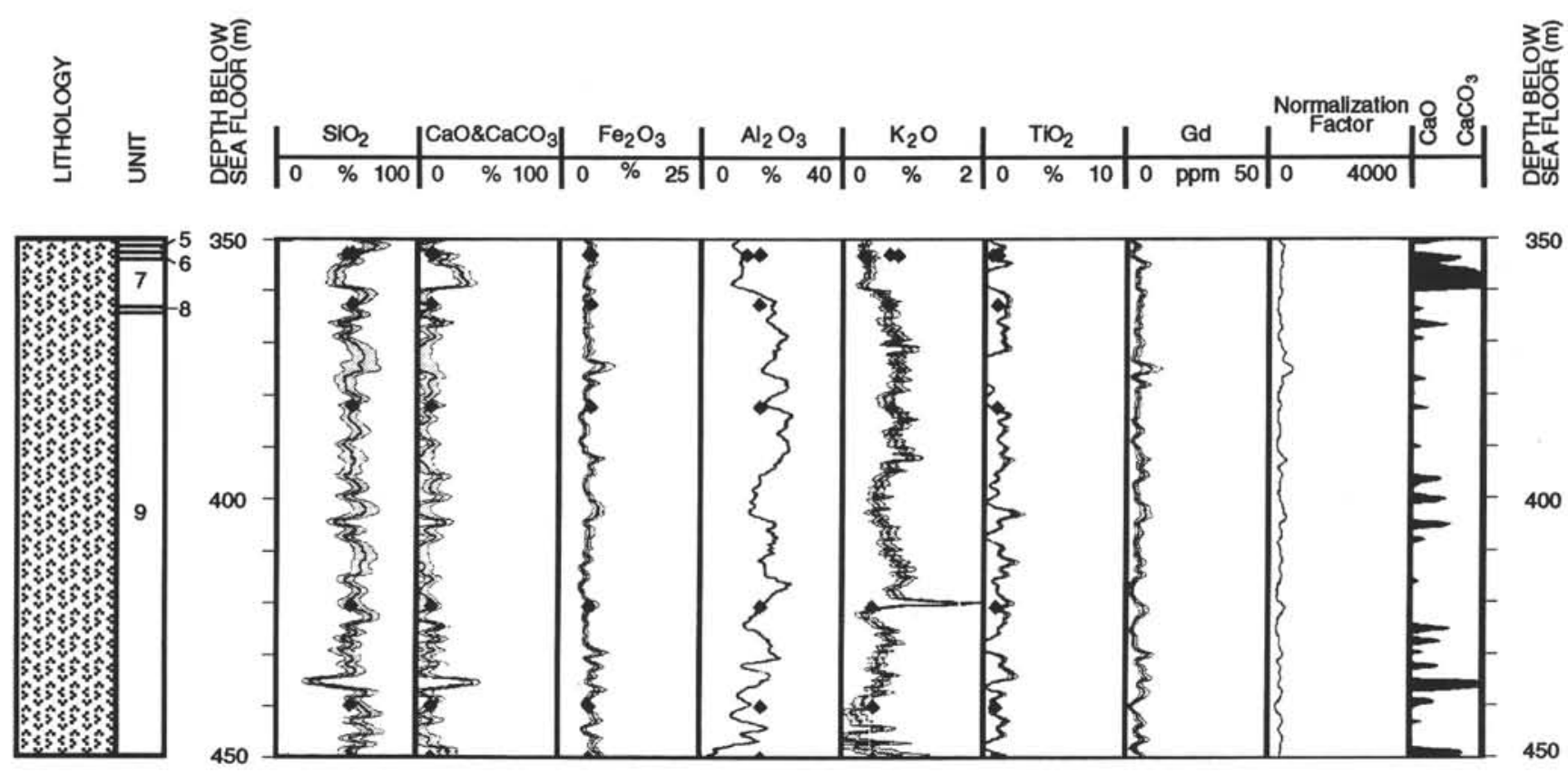

Figure 8 (continued) 

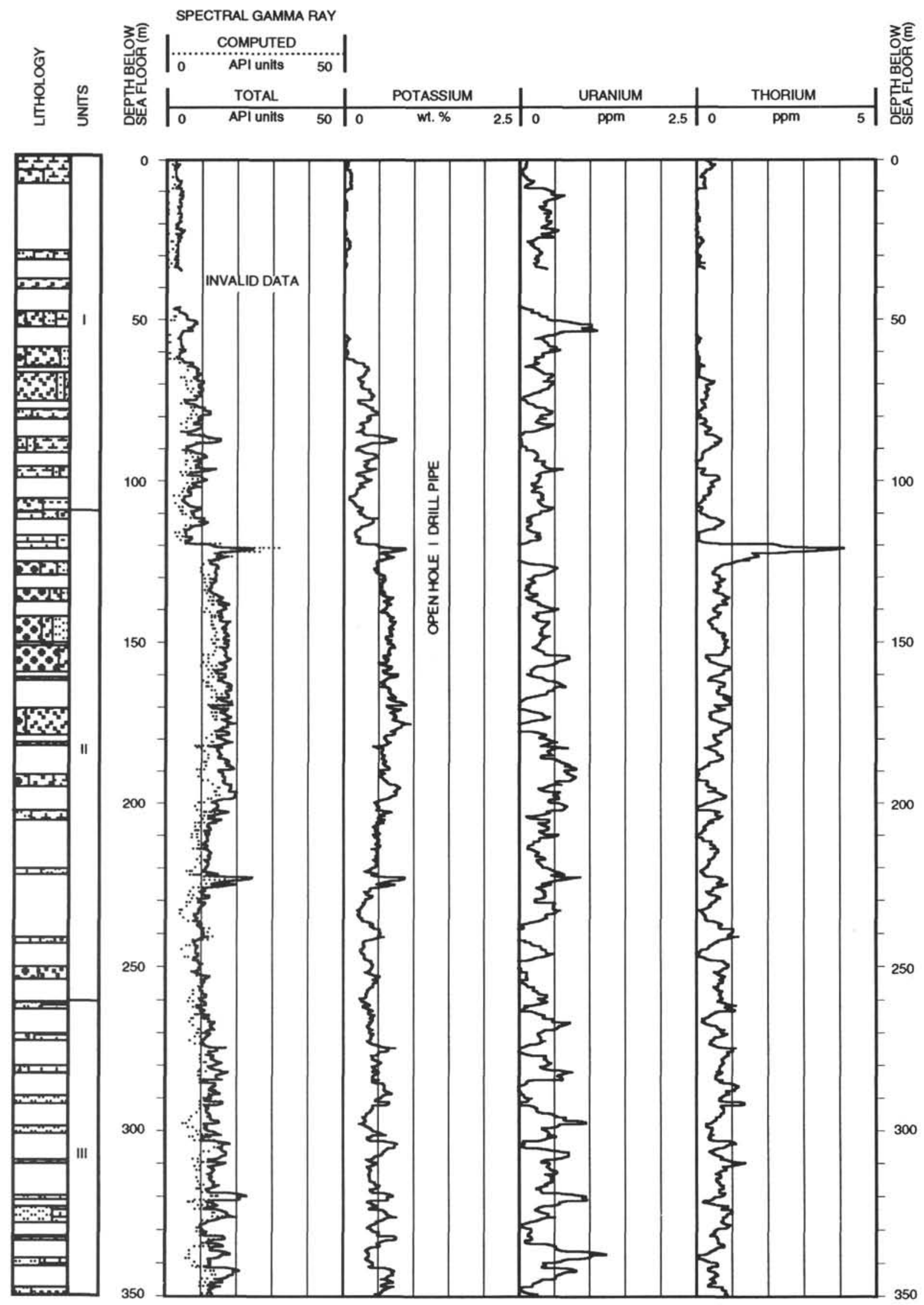

Figure 9. Processed natural gamma-ray data, Hole 840B. Legend as in Figure 3. 

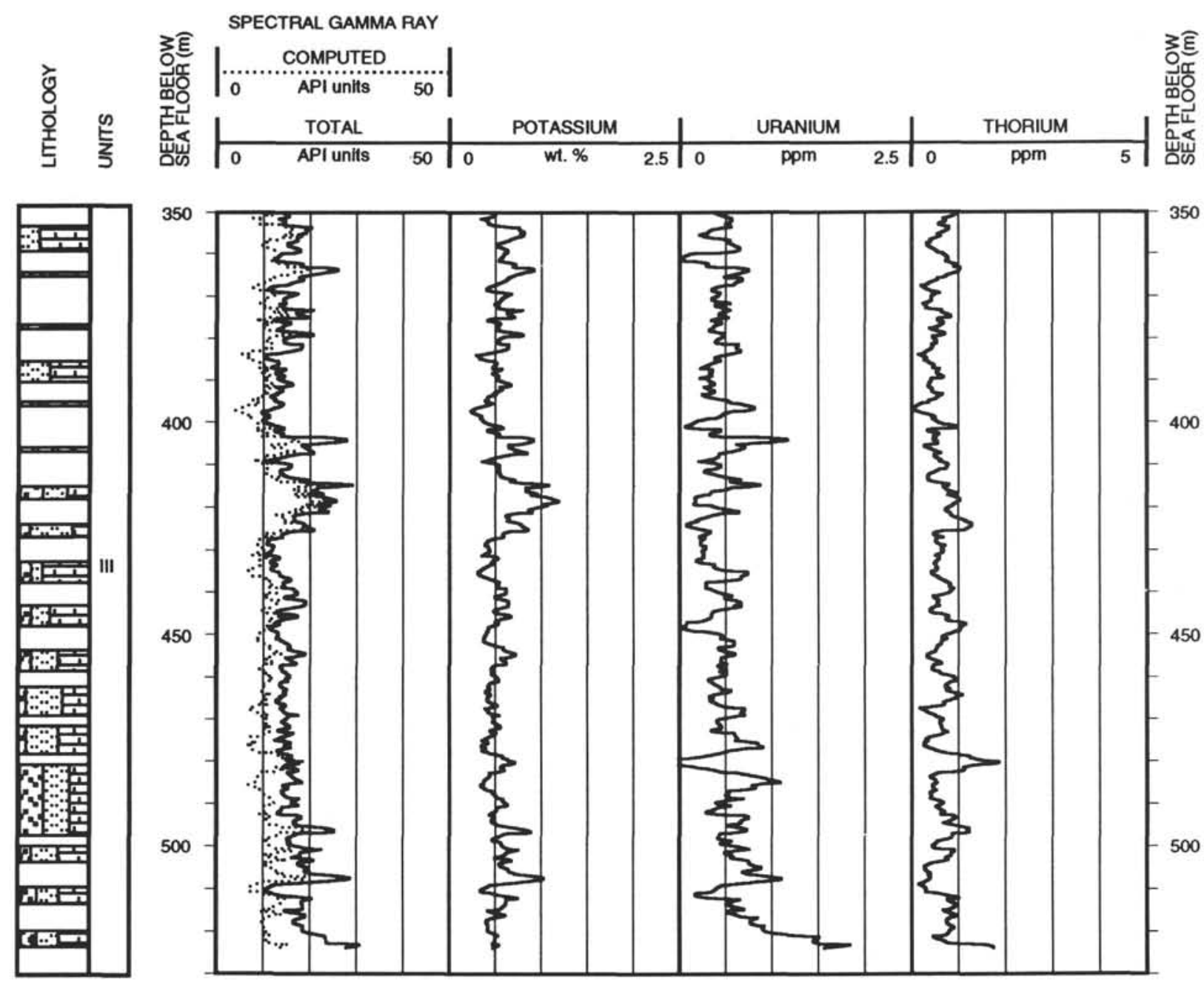

Figure 9 (continued). 


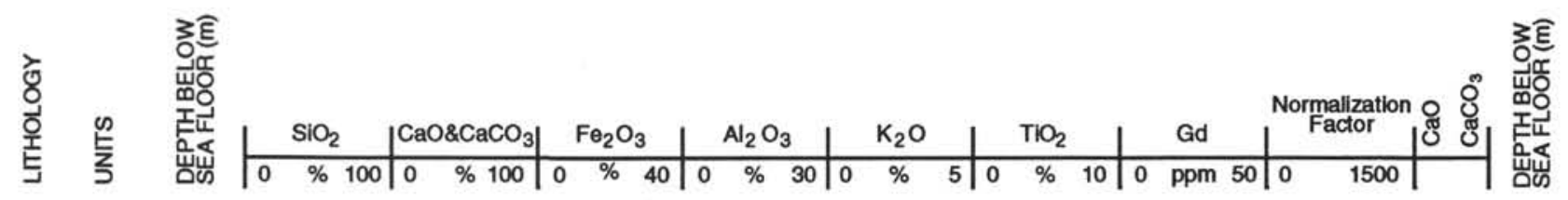

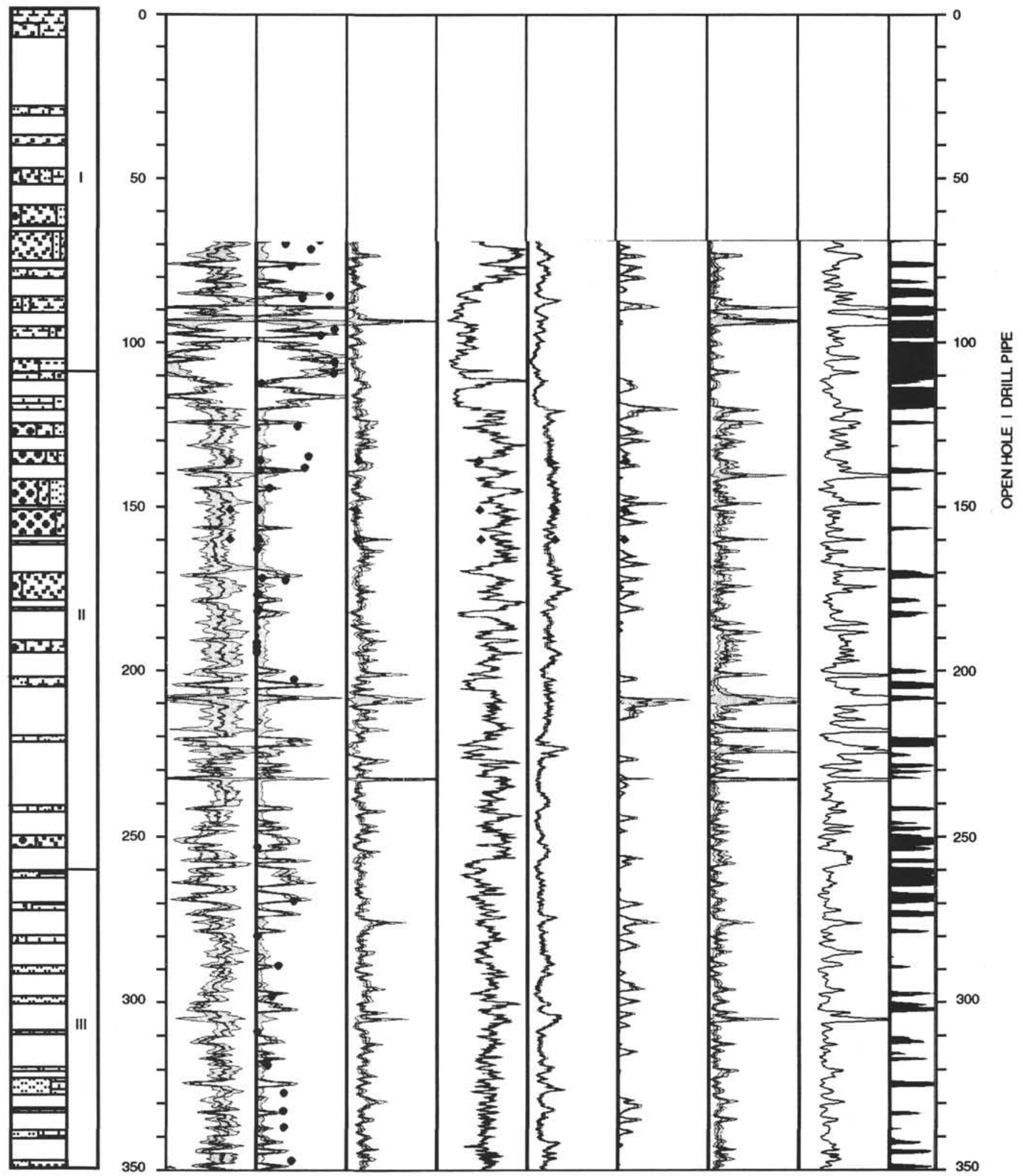

Figure 10. Calcium carbonate and major oxide-weight fractions from geochemical logs run in Hole 840B compared with core measurements. Legend as in Figure 3. 

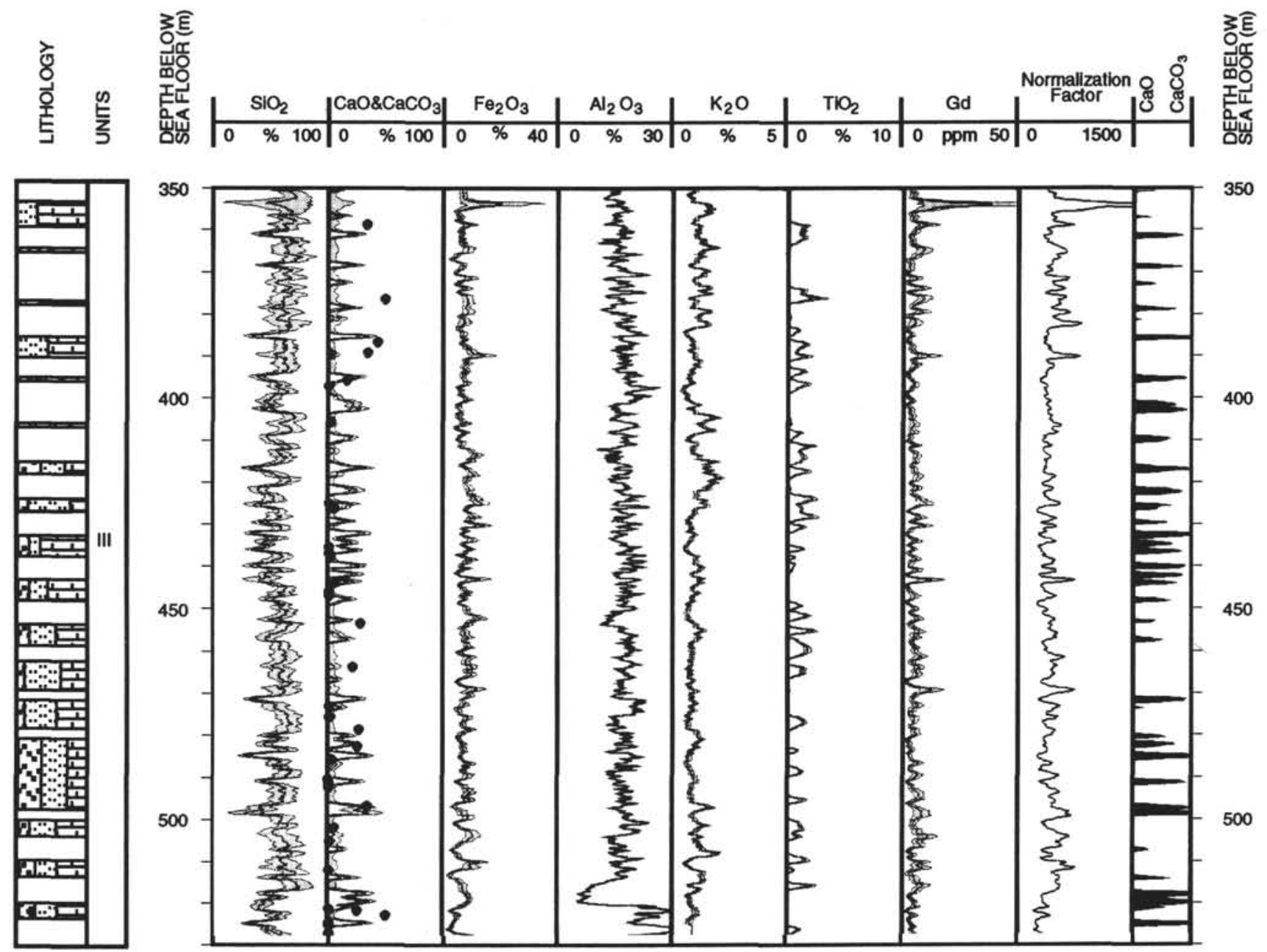

Figure 10 (continued). 